\title{
Effect of different fermentation strategies on Bacillus thuringiensis cultivation and its toxicity towards the bagworm, Metisa plana Walker (Lepidoptera: Psychidae)
}

\author{
Mohamed Mazmira Mohd Masri ${ }^{{ }^{*}}$ and Arbakariya Bin Ariff ${ }^{2}$
}

\begin{abstract}
The effect of batch and fed-batch fermentation on the cultivation performance of Bacillus thuringiensis was investigated using a 5-I stirred tank bioreactor. Significantly higher viable cell count $\left(>1.5 \times 10^{12} \mathrm{CFU} / \mathrm{ml}\right)$ was obtained in the fed-batch compared to batch fermentation $\left(1.4 \times 10^{12} \mathrm{CFU} / \mathrm{ml}\right)$. Glucose feeding during the fermentation seemed to enhance cell growth but failed to enhance the sporulation rate. It was found that sporulation and $\delta$-endotoxin synthesis in fed-batch fermentation could be enhanced by the application of optimal dissolved oxygen tension (DOT) control strategy without affecting the cell growth. Fed-batch cultivation with feeding at the exponential growth phase where the DOT was switched from 80 to $40 \%$ at $12 \mathrm{~h}$ of cultivation recorded the highest spore count of $7.1 \times 10^{11} \mathrm{spore} / \mathrm{ml}$. Cultures obtained from batch cultivation, as well as fedbatch cultivation with feeding at lag or exponential growth phase and the application of optimal DOT control strategy, recorded the presence of $\delta$-endotoxin; however, none was detected in intermittent fed-batch fermentation. Bioassay data against the bagworm Metisa plana Walker (Lepidoptera: Psychidae) recorded the highest corrected mortality (80\%) at 7 days of treatment (DAT), using the culture obtained from fed-batch cultivation with feeding during the exponential growth phase, and the DOT was switched from 80 to $40 \%$ at $12 \mathrm{~h}$ of cultivation. It is important to note that all cultures containing $\delta$-endotoxin exhibited $100 \%$ mortality towards $M$. plana at 14 DAT.
\end{abstract}

Keywords: Bacillus thuringiensis, Batch, Fed-batch, Cell growth, Sporulation rate, Metisa plana

\section{Background}

Bacillus thuringiensis $(B t)$ is widely used to control insect pests in the order Lepidoptera, Diptera, and Coleoptera (Yury et al. 2019). This bacterium produces spores that contain a proteinaceous body known as crystal protein or $\delta$-endotoxin that possesses insecticidal properties. These insecticidal proteins accumulate in the cell as crystal inclusions which constitute approximately $25 \%$ of the dry weight of the sporulated cells (Agaisse and Lereclus 1995). Bt is also very useful in controlling leaf defoliators such as bagworms (Noorhazwani et al. 2017). The currently recommended option to conserve the natural

\footnotetext{
* Correspondence: mazmira@mpob.gov.my

'Applied Entomology and Microbiology Unit, Biological Research Division,

Malaysian Palm Oil Board, 43000 Kajang, Selangor, Malaysia

Full list of author information is available at the end of the article
}

enemies is by using $B t$ for spraying against pest (Norman and Mazmira 2019).

Malaysian Palm Oil Board (MPOB) has established a local biopesticide product based on $B t$ known as Ecobac-1 (EC). The product has been used for ground and aerial spraying in smallholder areas and also plantations to combat the bagworm outbreak, especially in Perak and Johor (Mazmira et al. 2010). At least three consecutive aerial sprayings of $B t$ are required to control the bagworm population to below the threshold level (Noorhazwani et al. 2017). In Malaysia, severe economic losses are caused by two species of bagworm, namely Metisa plana Walker and Pteroma pendula Joannis (Lepidoptera: Psychidae) (Ramlah et al. 2007). The shortfalls due to bagworm attacks can cause up to 33-47\% yield losses, especially in oil palm (Basri et al. 1994). 
From the mid-1960s, bagworm outbreak became less common but started to surge again with more severity in the 1990s (Brian and Norman 2019). The bagworm species known as M. plana was classified as the most economically significant insect pest of oil palm (Basri et al. 1988). Bagworm infestation has been a serious issue affecting the yield of oil palm due to procrastinated and incorrect control strategy (Tey and Cheong 2013). In 2018, the total hectarage of oil palm infested areas, especially in the smallholdings, reached up to more than 30,000 ha, and the use of $B t$ based biopesticides has been the best alternative to control the pest.

Batch cultivation mode is frequently used to produce $B t$ spores with $\delta$-endotoxin (Rowe and Margaritis 1987; Avionone-Rossa and Mignone 1993; Adams et al. 1999). However, the kinetics of $B t$ in batch cultivation has not been studied extensively. A wide range of the maximum specific growth rate $\left(0.4-1.9 \mathrm{~h}^{-1}\right)$ for $B t$ has been reported (Avionone-Rossa and Mignone 1993), indicating the lack of a systematic study on growth kinetics of $B t$.

The final spore concentrations obtained in batch cultivation of $B t$ were relatively low and not exceeded $10^{11}$ spores/ml (Sarrafzadeh et al. 2005; Khodair et al. 2008; $\mathrm{Vu}$ et al. 2010). A mixture of $B t$ spores and crystals can be produced using different modes of cultivation (Aronson and Yechiel 2001). Many researchers have reported the use of fed-batch cultivation for the production of high-density cell culture (Stanbury et al. 2003; Krause et al. 2010; Warren et al. 2018). The maximum cell concentration obtained in fed-batch cultivation $(53.7 \mathrm{~g} / \mathrm{l})$ of Bt subspecies kurstaki was ninefold higher as compared to that obtained in batch cultivation $(5.9 \mathrm{~g} / \mathrm{l})$ (Liu et al. 1994). Kang et al. (1993) found that the fed-batch cultivation with a constant feeding did not produce sporulated cells even after cells were subsequently kept in the bioreactor and operated as batch mode.

Comprehensive reports on the effect of different modes of bioreactor operation on $B t$ cultivation for the production of spores with high entomotoxicity activities towards bagworm have not been reported in any literature. In this study, the cultivation performance was evaluated in terms of final cell concentration, percentage of sporulation, $\delta$-endotoxin synthesis, and also its toxicity towards M. plana.

\section{Materials and methods Microorganism}

Bacillus thuringiensis MPK13, obtained from the Malaysian Palm Oil Board (MPOB) culture collection, was used in this study (Mazmira et al. 2012). This bacterium was isolated from the gut of the dead larvae of bagworm M. plana through several isolation steps. The isolated bacterium was then grown on nutrient agar and stored at $4{ }^{\circ} \mathrm{C}$ as a stock culture (Mazmira et al. 2013).

\section{Media and inoculum preparation}

The preferred medium for the cultivation of $B t$ with high sporulation rate and $\delta$-endotoxin production as described earlier (Içygen et al. 2002; Mazmira et al. 2012) was used in this study. The medium consisted of $\left(\mathrm{NH}_{4}\right)_{2} \mathrm{SO}_{4}, 2.0 \mathrm{~g} / \mathrm{l} ; \mathrm{K}_{2} \mathrm{HPO}_{4} \cdot 3 \mathrm{H}_{2} \mathrm{O}, 0.5 \mathrm{~g} / \mathrm{l} ; \mathrm{MgSO}_{4} \cdot 7 \mathrm{H}_{2} \mathrm{O}$, $0.2 \mathrm{~g} / \mathrm{l} ; \mathrm{MnSO}_{4} .4 \mathrm{H}_{2} \mathrm{O}, 0.05 \mathrm{~g} / \mathrm{l} ; \mathrm{CaCl}_{2} .2 \mathrm{H}_{2} \mathrm{O}, 0.08 \mathrm{~g} / \mathrm{l}$; and yeast extract, $2.0 \mathrm{~g} / \mathrm{l}$. The initial $\mathrm{pH}$ was adjusted at 6.5 . Glucose at a concentration of $8.0 \mathrm{~g} / \mathrm{l}$ was added to the basal medium. Glucose needs to be separately sterilized at $110^{\circ} \mathrm{C}$ for $10 \mathrm{~min}$ before being added to the medium. The feed medium used for fed-batch fermentation was similar to the original medium in all aspects. For inoculum preparation, the $B t$ colony from the stock was inoculated into $400 \mathrm{ml}$ of sterile nutrient broth in 11 Erlenmeyer flask. The flask was then incubated at $30^{\circ} \mathrm{C}$ in rotary orbital shaker agitated at $150 \mathrm{rpm}$ for $14 \mathrm{~h}$. The culture was then used as a standard inoculum for all cultivations, using a 5-l stirred tank bioreactor.

\section{Stirred tank bioreactor}

All modes of cultivations investigated in this study were conducted using a 5-l stirred tank bioreactor (BIOSTAT B-DCU, Sartorius Stedim, Germany). The standard sixbladed Rushton turbine impeller (diameter $=0.05 \mathrm{~m}$ ) was used for bubble dispersion and mixing while ring sparger was used for air sparging. The agitation speed was controlled in the range of 50 to $500 \mathrm{rpm}$, and the temperature was maintained at $30^{\circ} \mathrm{C}$ throughout the cultivations. The control system provided the regulation of the mixing speed (50-500 rpm) as well as the regulation of the stirrer working time. The airflow was set at one $\mathrm{v} / \mathrm{v} / \mathrm{m}$. Silicone KM72FS (Shin-Etsu, Japan) at 10\% was used as an antifoam agent. The dissolved oxygen tension (DOT) regulation during the cultivation was obtained with variations of agitation speed. Samples (20 $\mathrm{ml}$ ) were withdrawn every $4 \mathrm{~h}$ intervals to determine the total viable cell count, spore count, sporulation rate, and $\delta$-endotoxin synthesis.

\section{Batch cultivation}

Actively growing seed from the inoculum was used to inoculate the bioreactor at $11 \% \mathrm{v} / \mathrm{v}$. The medium (3.6l) was sterilized at $121^{\circ} \mathrm{C}, 15 \mathrm{psi}$ for $15 \mathrm{~min}$. The batch cultivation was started by inoculating the inoculum into the 5-1 bioreactor. The temperature was maintained at $30^{\circ} \mathrm{C}$. The DOT level was controlled at $80 \%$ by variation in agitation speed ranging from 50 to $500 \mathrm{rpm}$ using a cascade model of DOT control module.

\section{Fed-batch cultivation}

The schematic diagram of the equipment setup for fedbatch cultivation is shown in Fig. 1. Initial batch bioreactor operation conditions for subsequent fed-batch were 


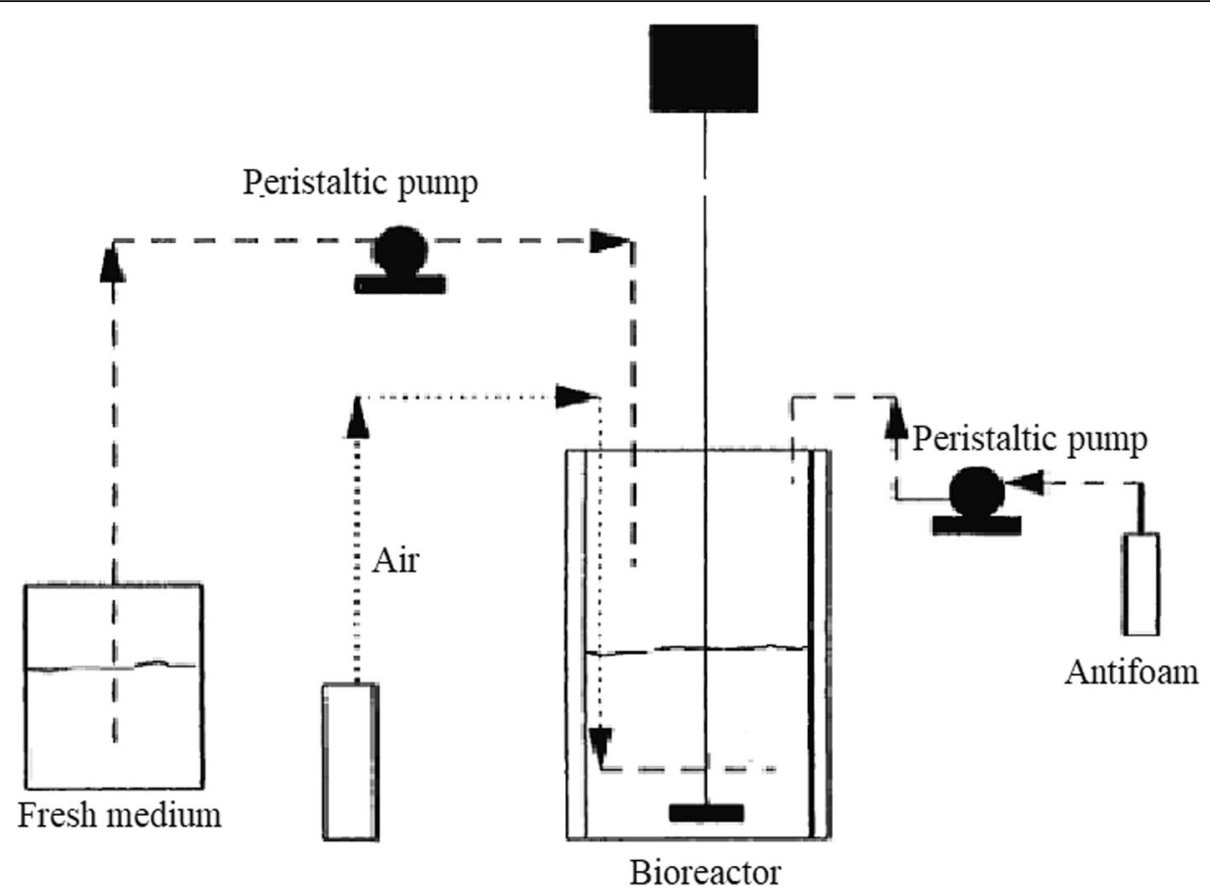

Fig. 1 Schematic diagram of the equipment setup for fed-batch cultivation

the same as batch cultivation, but the culture was reduced to $2 \mathrm{l}$. During fed-batch cultivation, a peristaltic pump (Watson-Marlow $101 \mathrm{U} / \mathrm{R}$, England) was used to feed the fresh substrate into the bioreactor. The fedbatch feeding strategy was modified from the method reported by Rech and Ayub (2007).

Two types of feeding strategies (constant and intermittent feeding) were applied in fed-batch cultivation. In constant fed-batch cultivations, fresh medium was fed to the bioreactor at a constant rate during three different growth phases: (1) lag growth phase, (2) exponential growth phase, and (3) stationary growth phase. In intermittent fed-batch cultivations, fresh medium was intermittently fed to the bioreactor at two different growth phases: (1) exponential growth phase (6 $\mathrm{h}$ of cultivation) and (2) stationary growth phase (24 h of cultivation). Cultivation conditions in all fed-batch were similar to batch cultivations and the DOT was not controlled but monitored throughout the process.

$\delta$-Endotoxin synthesis by $B t$ could be enhanced in batch cultivation when the DOT was controlled at $80 \%$ saturation during the active growth phase and then switched to $40 \%$ saturation during the middle of the exponential growth phase. This DOT control strategy was also applied in fed-batch cultivation with feeding at lag and exponential growth phases. In fed-batch cultivation with feeding at lag phase ( $2 \mathrm{~h}$ of cultivation), the DOT was switched from 80 to $40 \%$ saturation at $8 \mathrm{~h}$ of cultivation. While in fed-batch with medium feeding at exponential growth phase ( $6 \mathrm{~h}$ of cultivation), the DOT was switched from 80 to $40 \%$ saturation at $12 \mathrm{~h}$ of cultivation.

\section{Analytical procedures}

During the cultivation, culture samples were collected at different time intervals for analysis. The culture samples were serially diluted using $0.85 \%(\mathrm{v} / \mathrm{v})$ sterilized saline buffers and plated on nutrient agar (NA) plates. The plates were incubated at $30{ }^{\circ} \mathrm{C}$ for $48 \mathrm{~h}$ and the number of the single colonies developed was counted and expressed in CFU/ml. For spore count, the culture samples were heated at $80{ }^{\circ} \mathrm{C}$ for $15 \mathrm{~min}$ to kill the vegetative cells before serially diluted and plated on NA plates. The plates were incubated at $30^{\circ} \mathrm{C}$ for $48 \mathrm{~h}$ and the number of the single colonies developed was counted and expressed as spores/milliliter (Thompson and Stevenson 1984).

\section{Gel electrophoresis}

SDS-PAGE analysis was conducted using the Laemmli method (Laemmli 1970). The Laemmli system is a discontinuous SDS system that is the most widely used electrophoretic system. The resolution in a Lemmli gel is excellent because the treated peptides are concentrates in a stacking gel before entering the separating gel. To set up two sets of gels for Hoefer unit, running gel consisting of $5 \mathrm{ml}$ monomer solution (A:B), $15 \mathrm{ml} 4 \times$ running buffer $600 \mu \mathrm{l}, 10 \%$ Of SDS, and $29.1 \mathrm{ml}$ of distilled water. The gel solution was vacuumed for $15 \mathrm{~min}$ and after that $300 \mu \mathrm{l}$ of $10 \%$ ammonium persulfate and $20 \mu \mathrm{l}$ 
of Temed was added. The ammonium persulfate must be prepared fresh. The running gel solution was poured into the Hoefer unit. Stacking gel contains $2.6 \mathrm{ml}$ monomer (A:B), an aliquot of $5 \mathrm{ml}$ stacking gel buffer, and $200 \mu \mathrm{l} 10 \%$ SDS. Before the samples were loaded into the gel, an aliquot of $2 \times$ treatment buffer was added and incubated in a water bath at $100^{\circ} \mathrm{C}$ for $90 \mathrm{~s}$. Aliquot of $80 \mu \mathrm{l}$ of each sample was loaded into each well of the gel. Aliquot of $10 \mu \mathrm{l}$ of $10 \mathrm{kD}$ marker was also loaded into the gel. After the samples were loaded into the wells, electric current was set up at $15 \mathrm{~A}$ and left overnight.

\section{Laboratory bioassay towards Metisa plana}

The efficacy of the $B t$ cells cultivated in different modes of bioreactor operation was carried out against early instar of M. plana. The spray suspensions were prepared by diluting the $B t$ culture samples obtained from the cultivation with sterile distilled water. Bioassay samples were taken at $48 \mathrm{~h}$ of cultivation from samples which contain $\delta$-endotoxin. The control treatment was prepared by spraying sterile distilled water on the palm leaves. The $B t$ suspension was then sprayed uniformly on the palm leaves dipped in reverse osmosis water. After the spray became dry, five larvae (early instars) were placed on the sprayed leaves. Each experiment was performed in four replicates. The observation of larval mortality was recorded at different days $(1,3,7$, and until 13) after treatment (DAT). Data on mortality was converted to corrected mortality using the Abbot Formula (Abbott 1987):

$$
\begin{aligned}
\text { Corrected mortality }= & {[\% \text { treatment }-\% \text { control } / 100-\% \text { c }} \\
& \times 100 \%
\end{aligned}
$$

\section{Results and discussion}

\section{Batch cultivation of Bt MPK13}

The time course of batch cultivation of Bt MPK13 in a 5-1 stirred tank bioreactor is shown in Fig. 2. The results showed that high cell growth and sporulation could be obtained during batch cultivation. The high cell growth $\left(>1.0 \times 10^{11} \mathrm{CFU} / \mathrm{ml}\right)$ was achieved as early as $8 \mathrm{~h}$ of cultivation. The highest cell growth $\left(1.4 \times 10^{12} \mathrm{CFU} / \mathrm{ml}\right)$ and highest spore count $\left(4.7 \times 10^{11} \mathrm{CFU} / \mathrm{ml}\right)$ were recorded at $48 \mathrm{~h}$ of cultivation, respectively. During batch cultivation, log phase was recorded as early as $4 \mathrm{~h}$ of fermentation until $20 \mathrm{~h}$ of cultivation, which lasted for $16 \mathrm{~h}$. The cells started to enter the stationary phase starting from $24 \mathrm{~h}$ of cultivation. The highest percentage of the sporulation rate recorded in batch cultivation was 37\% (Table 1). Glucose was completely consumed at $28 \mathrm{~h}$ of cultivation (Fig. 2). Bt MPK13 cells efficiently consumed glucose to support the growth process. Maximum cell

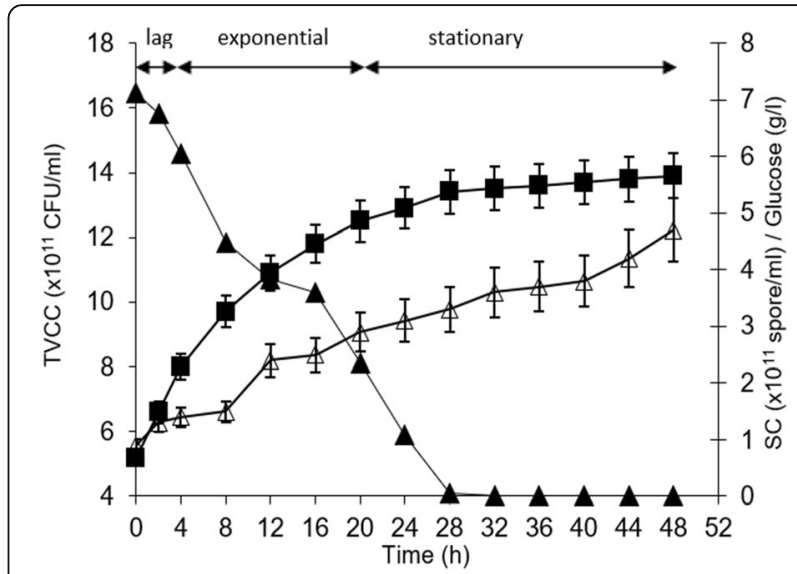

Fig. 2 Typical time course of batch cultivation of Bacillus thuringiensis MPK13. Black square denotes the total viable cell count (CFU/ml), white triangle spore count, and black triangle glucose concentration

productivity $\left(72 \times 10^{11} \mathrm{CFU} / \mathrm{l} / \mathrm{h}\right)$ and spore productivity $\left(25 \times 10^{11}\right.$ spore $\left./ \mathrm{l} / \mathrm{h}\right)$ were recorded at $48 \mathrm{~h}$ of cultivation (Table 1).

\section{Fed-batch cultivation of $B t$ MPK13 Feeding during the lag growth phase}

The time course of fed-batch cultivation of Bt MPK13, with fresh medium feeding at $2 \mathrm{~h}$ of cultivation in a 5-1 stirred tank bioreactor, is shown in Fig. 3a. The feeding time was initiated at $2 \mathrm{~h}$ of cultivation based on the lag phase of the growth profile obtained during batch cultivation. It was found that substrate feeding during the lag phase has substantially delayed the exponential phase for appoloximately $4 \mathrm{~h}$. The highest cell count $\left(14.7 \times 10^{11}\right.$ $\mathrm{CFU} / \mathrm{ml}$ ) in fed-batch cultivation with feeding during the lag phase and the highest spore count $\left(3.7 \times 10^{11}\right.$ spore/ $\mathrm{ml}$ ) were recorded at $48 \mathrm{~h}$ of cultivation (Table 1$)$. The exponential growth phase in fed-batch cultivation with feeding during lag phase lasted for $20 \mathrm{~h}$ as compared to $16 \mathrm{~h}$ in batch cultivation, as shown in Fig. 3a. The extension of the exponential growth phase may be due to the addition of fresh substrate during the lag growth phase. Glucose concentration in the culture was completely utilized by the cells at $44 \mathrm{~h}$ of cultivation. Maximum cell productivity $\left(73 \times 10^{11} \mathrm{CFU} / \mathrm{l} / \mathrm{h}\right)$ and spore productivity $\left(19 \times 10^{11}\right.$ spore $\left./ \mathrm{l} / \mathrm{h}\right)$ were recorded at $48 \mathrm{~h}$ of cultivation (Table 1).

\section{Feeding during exponential growth phase}

The highest cell count $\left(15.8 \times 10^{11} \mathrm{CFU} / \mathrm{ml}\right)$ and spore count $\left(3.9 \times 10^{11}\right.$ spore $\left./ \mathrm{ml}\right)$ were recorded at 40 and 48 h of cultivation, respectively (Table 1 ). Feeding of glucose during the exponential growth phase resulted in the extension of the phase ( $24 \mathrm{~h}$ ) as compared to only $16 \mathrm{~h}$ for batch cultivation. As shown in Fig. 3b, glucose 
Table 1 Comparison of cell growth, sporulation and $\delta$-endotoxin production by Bacillus thuringiensis MPK13 in batch and fed-batch cultivations

\begin{tabular}{|c|c|c|c|c|c|c|c|c|}
\hline $\begin{array}{l}\text { Fermentation } \\
\text { mode }\end{array}$ & $\begin{array}{l}\text { Max cell count } \\
\left(\times 10^{11} \text { CFU/ }\right. \\
\mathrm{ml})\end{array}$ & $\begin{array}{l}\text { Max spore } \\
\text { count }\left(\times 10^{11}\right. \\
\text { spore } / \mathrm{ml})\end{array}$ & $\begin{array}{l}\text { Increase in } \\
\text { cell count } \\
(\%)^{a}\end{array}$ & $\begin{array}{l}\text { Decrease in } \\
\text { spore count } \\
(\%)^{\mathrm{b}}\end{array}$ & $\begin{array}{l}\delta- \\
\text { endotoxin }\end{array}$ & $\begin{array}{l}\text { Max percentage } \\
\text { of sporulation } \\
(\%)\end{array}$ & $\begin{array}{l}\text { Max cell } \\
\text { productivity }(\times \\
\left.10^{8} \mathrm{CFU} / \mathrm{l} / \mathrm{h}\right)\end{array}$ & $\begin{array}{l}\text { Max spore } \\
\text { productivity }\left(\times 10^{8}\right. \\
\text { spore///h) }\end{array}$ \\
\hline Batch & $13.9(48 \mathrm{~h})$ & $5.2(48 h)$ & 0 & 0 & Yes (36 h) & 37 (48 h) & 72.4 & 24.5 \\
\hline \multicolumn{9}{|c|}{ Fed-batch Feed during: } \\
\hline $\begin{array}{l}\text { 1) Lag } \\
\text { phase (2 h) }\end{array}$ & $14.7(48 \mathrm{~h})$ & 3.7 (48 h) & 5.8 & 28.8 & Yes (48 h) & 25 (48 h) & 73.4 & 19.3 \\
\hline $\begin{array}{l}\text { 2) Log } \\
\text { phase }(6 \mathrm{~h})\end{array}$ & 15.8 (40 h) & 3.9 (48 h) & 13.7 & 25.0 & Yes (48 h) & 25 (48 h) & 98.8 & 20.3 \\
\hline $\begin{array}{l}\text { 3) } \\
\text { Stationary } \\
\text { phase }(24 \\
\text { h) }\end{array}$ & $16.1(48 \mathrm{~h})$ & $3.1(48 h)$ & 15.8 & 40.0 & No & $21.5(24 \mathrm{~h})$ & 83.9 & 16.1 \\
\hline $\begin{array}{l}\text { Intermittent } \\
\text { fed-batch }\end{array}$ & $17.2(48 \mathrm{~h})$ & 2.6 (48h) & 23.7 & 50.0 & No & $15.2(36 h)$ & 89.6 & 13.5 \\
\hline
\end{tabular}

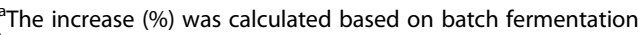

${ }^{\mathrm{b}}$ The decrease (\%) was calculated in comparison with batch cultivation data

concentration in the culture was entirely utilized by the cells after $36 \mathrm{~h}$ of cultivation, which was at the stationary growth phase. Maximum sporulation rate, maximum cell productivity, and maximum spore productivity for this cultivation was $25 \%, 99 \times 10^{11} \mathrm{CFU} / \mathrm{l} / \mathrm{h}$, and $20.3 \times 10^{11}$ spore $/ \mathrm{l} / \mathrm{h}$, respectively.

\section{Feeding during stationary growth phase}

The time course of fed-batch cultivation of Bt MPK13 with fresh medium feeding at $24 \mathrm{~h}$ of cultivation is shown in Fig. 3c. Feeding of glucose during the stationary phase resulted in the highest cell growth $(16.1 \times$ $\left.10^{11} \mathrm{CFU} / \mathrm{ml}\right)$ and highest spore count $\left(3.1 \times 10^{11}\right.$ spore/ $\mathrm{ml})$ at $48 \mathrm{~h}$ of cultivation. Maximum sporulation (22\%) was recorded at $24 \mathrm{~h}$ of cultivation (Table 1 ). The final glucose concentration at $48 \mathrm{~h}$ of cultivation was $1.3 \mathrm{~g} / \mathrm{l}$ (Fig. 3c). Maximum productivity for cells and spore during fed-batch cultivation with feeding during the stationary growth phase was $84 \times 10^{11} \mathrm{CFU} / \mathrm{l} / \mathrm{h}$ and $16 \times 10^{11}$ CFU/l/h, respectively (Table 1 ).

\section{Intermittent feeding during log and stationary phase}

The time courses of intermittent fed-batch cultivation of Bt MPK13 with fresh medium feeding at 6 and $24 \mathrm{~h}$ of cultivation are shown in Fig. 4. The highest cell count $\left(17.2 \times 10^{11} \mathrm{CFU} / \mathrm{ml}\right)$ and spore count $\left(2.6 \times 10^{11}\right.$ spore/ ml) was recorded at $48 \mathrm{~h}$ of cultivation (Table 1). Glucose concentration at $48 \mathrm{~h}$ of cultivation was $1.0 \mathrm{~g} / \mathrm{l}$ (Fig. 4). The maximum productivity for viable cells and spores for this cultivation was $90 \times 10^{11} \mathrm{CFU} / \mathrm{l} / \mathrm{h}$ and $13.5 \times 10^{11} \mathrm{CFU} / \mathrm{l} / \mathrm{h}$, respectively (Table 1 ).

\section{Fed-batch with optimal DOT control strategy}

In fed-batch cultivation with fresh medium, feeding at lag growth phase and the DOT was switched from 80 to
$40 \%$ at $8 \mathrm{~h}$ of cultivation, and the highest cell growth $\left(14.7 \times 10^{11} \mathrm{CFU} / \mathrm{ml}\right)$ and the highest spore count $(6.6 \times$ $10^{11}$ spore $/ \mathrm{ml}$ ) were recorded at $48 \mathrm{~h}$ of cultivation (Table 2). The highest sporulation percentage (45.9\%) was also recorded at $48 \mathrm{~h}$ of cultivation. The cell and spore productivity for this cultivation was $77 \times 10^{11}$ $\mathrm{CFU} / \mathrm{ml} / \mathrm{h}$ and $30 \times 10^{11}$ spore $/ \mathrm{ml} / \mathrm{h}$, respectively.

In addition, fed-batch cultivation with fresh medium feeding at exponential growth phase and DOT was switched from 80 to $40 \%$ at $12 \mathrm{~h}$ of cultivation, and the highest cell growth $\left(14.5 \times 10^{11} \mathrm{CFU} / \mathrm{ml}\right)$ and the highest spore count $\left(7.1 \times 10^{11}\right.$ spore $\left./ \mathrm{ml}\right)$ were recorded at $48 \mathrm{~h}$ of cultivation (Table 2). The highest percentage of sporulation $(49.0 \%)$ was also recorded at $48 \mathrm{~h}$ of cultivation. The cell and spore productivity for this cultivation was $75.5 \times 10^{11} \mathrm{CFU} / \mathrm{ml} / \mathrm{h}$ and $37 \times 10^{11}$ spore $/ \mathrm{ml} / \mathrm{h}$, respectively. Bt MPK13 cells in fed-batch cultivation with feeding at exponential growth phase and DOT were switched at $12 \mathrm{~h}$ had a high capability to sporulate than the cells in fed-batch cultivation with feeding at lag growth phase, and DOT was switched at $8 \mathrm{~h}$ of cultivation.

\section{Comparison of cultivation performance in different modes of bioreactor operation}

The cultivation performance of Bt MPK13 in different modes of bioreactor operation was presented in Table 1. The lowest cell count $\left(1.4 \times 10^{12} \mathrm{CFU} / \mathrm{ml}\right)$ and the lowest cell productivity $\left(72 \times 10^{8} \mathrm{CFU} / \mathrm{l} / \mathrm{h}\right)$ was obtained in batch cultivation, though considerably high spore productivity was achieved $\left(25 \times 10^{8} \mathrm{CFU} / \mathrm{l} / \mathrm{h}\right)$. Increased cell count by about $6 \%$ was obtained in fedbatch cultivation by feeding during lag growth phase than in the batch cultivation. However, the percentage of sporulation $(25 \%)$ was lower than that obtained in 

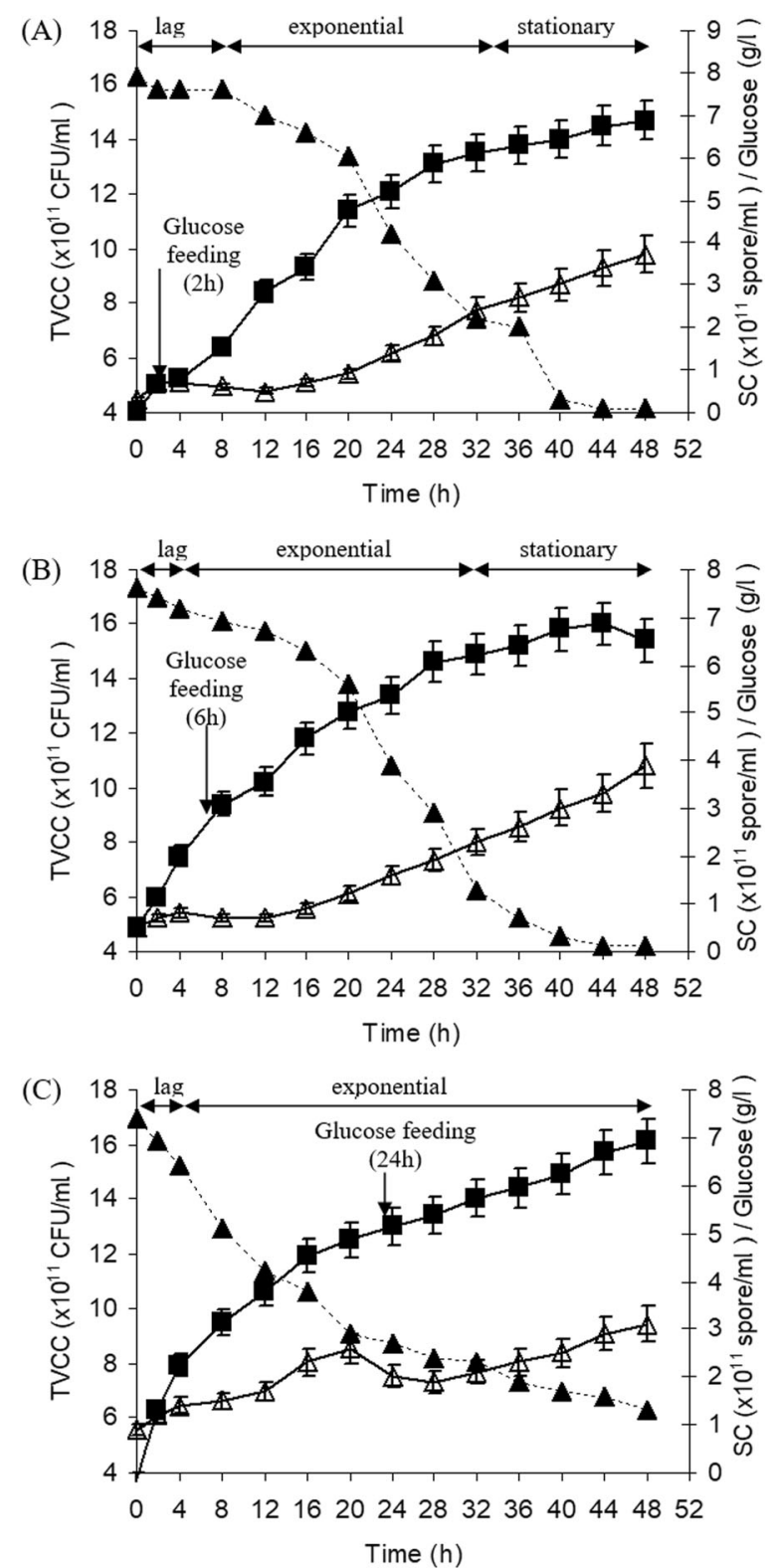

Fig. 3 Typical time course of fed-batch cultivation of Bacillus thuringiensis MPK13 with a constant feeding of fresh medium (a feeding at lag growth phase; $\mathbf{b}$ feeding at exponential growth phase; $\mathbf{c}$ feeding at stationary growth phase). Black square denotes the total viable cell count (CFU/ml), white triangle spore count, and black triangle glucose concentration

batch cultivation (37\%). In fed-batch cultivation with feeding at the exponential growth phase, a $14 \%$ increase in cell growth was recorded than in the batch cultivation. However, spore count decreased by about $25 \%$ than that obtained in batch cultivation (Table 1). In fed-batch cultivation with feeding at the stationary growth phase, a $16 \%$ increase in cell count was recorded. However, a substantial decrease in spore count $(40 \%)$ was recorded compared to that obtained in the

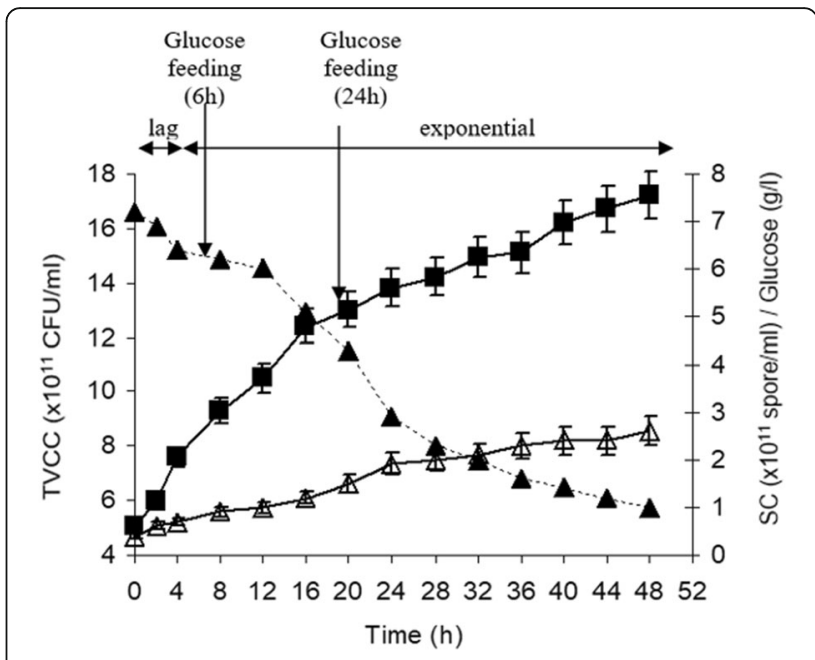

Fig. 4 Typical time course of fed-batch cultivation of Bacillus thuringiensis MPK13 with intermittent feeding of fresh medium (feeding at exponential and stationary growth phase). Black square denotes the total viable cell count (CFU/ml), white triangle spore count, and black triangle glucose concentration

batch cultivation. In addition, glucose was not fully consumed in fed-batch cultivation, fed during the stationary growth phase (Fig. 3c), suggesting that glucose was not required for sporulation.

Among all cultivation modes tested in this study, the highest viable cell count $\left(1.7 \times 10^{12} \mathrm{CFU} / \mathrm{ml}\right)$ was obtained in intermittent fed-batch cultivation. In comparison with batch cultivation, approximately $24 \%$ increase in cell count was recorded in intermittent fed-batch cultivation (Table 1). However, a substantial reduction in spore count $\left(2.6 \times 10^{11}\right.$ spore $\left./ \mathrm{ml}\right)$ was obtained in this cultivation. Substantial enhancement in the percentage of sporulation was achieved in fed-batch cultivation when the optimal DOT control strategy was applied. The highest sporulation percentage (49\%), spore productivity $\left(37 \times 10^{11}\right.$ spore/l/h), and spore count $(7.1 \times$ $10^{11} \mathrm{spore} / \mathrm{ml}$ ) were recorded in fed-batch cultivation with medium at exponential growth phase, where DOT was switched from 80 to $40 \%$ at $12 \mathrm{~h}$ of cultivation (Table 2). Fed-batch cultivation of $B t$, without appropriate DOT control strategy, enhanced cell growth but not the percentage of sporulation.

In the cultivation of Bt MPK13, glucose was identified as the most critical nutrient that supports both viable cell growth and also sporulation (Mazmira et al. 2012). Reports on the empirical feeding policies have been developed to achieve high cell density culture (Khodair et al. 2008). In this experiment, the excess feeding of glucose seemed to decrease sporulation and also blocked the synthesis of $\delta$-endotoxin. Intermittent feeding of glucose at exponential and stationary growth phase, as well 
Table 2 Comparison of cell growth, sporulation, and $\delta$-endotoxin production by Bacillus thuringiensis MPK13 in fed-batch cultivation with the optimal DOT control strategy

\begin{tabular}{|c|c|c|c|c|c|c|c|c|}
\hline Fed-batch with aeration strategy & $\begin{array}{l}\text { Max cell } \\
\text { count }(\times \\
10^{11} \mathrm{CFU} / \\
\mathrm{ml})\end{array}$ & $\begin{array}{l}\text { Max spore } \\
\text { count }(\times \\
10^{11} \text { spore/ } \\
\mathrm{ml})\end{array}$ & $\begin{array}{l}\text { Increase } \\
\text { in cell } \\
\text { count } \\
(\%)^{a}\end{array}$ & $\begin{array}{l}\text { Increase } \\
\text { in spore } \\
\text { count } \\
(\%)^{b}\end{array}$ & $\begin{array}{l}\delta \text { - } \\
\text { endotoxin }\end{array}$ & $\begin{array}{l}\text { Max } \\
\text { percentage } \\
\text { of } \\
\text { sporulation } \\
(\%) \\
\end{array}$ & $\begin{array}{l}\text { Max cell } \\
\text { productivity } \\
\left(\times 10^{11} \text { CFU/ }\right. \\
\text { l/h })\end{array}$ & $\begin{array}{l}\text { Max spore } \\
\text { productivity } \\
\left(\times 10^{11} \text { spore/ }\right. \\
\text { l/h })\end{array}$ \\
\hline $\begin{array}{l}\text { Medium feeding at lag growth phase } \\
(2 \mathrm{~h} \text { ) (DOT was switched from } 80 \% \text { to } \\
40 \% \text { at } 8 \mathrm{~h} \text { of cultivation) }\end{array}$ & $14.7(48 \mathrm{~h})$ & 6.6 (48 h) & 5.8 & 26.9 & $\begin{array}{l}\text { Yes (24- } \\
48 \text { h) }\end{array}$ & $45.9(48 \mathrm{~h})$ & 76.6 & 30.2 \\
\hline $\begin{array}{l}\text { Medium feeding at exponential growth } \\
\text { phase ( } 6 \mathrm{~h} \text { ) (DOT was switched from } \\
80 \% \text { to } 40 \% \text { at } 12 \mathrm{~h} \text { of cultivation) }\end{array}$ & $14.5(48 \mathrm{~h})$ & 7.1 (48 h) & 4.3 & 36.5 & $\begin{array}{l}\text { Yes (28- } \\
48 \text { h) }\end{array}$ & 49.0 (48h) & 75.5 & 37.0 \\
\hline
\end{tabular}

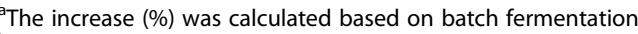

${ }^{\mathrm{b}}$ The decrease (\%) was calculated in comparison with batch cultivation data

as continuous feeding of glucose throughout the cultivation, successfully promoted high cell growth $(\geq 1.6 \times$ $\left.10^{11} \mathrm{CFU} / \mathrm{ml}\right)$. However, sporulation was reduced by a spore count of less than $<3.5 \times 10^{11} \mathrm{CFU} / \mathrm{ml}$ ). Although the existence of glucose is crucial for sporulation, high concentration in the culture may disturb the initiation of the sporulation process. It is well noted that sporulation and germination in bacilli are dependent on the nutritional status of the microorganisms (Rajalakshmi and Shethna 1980).

Sporulation and cry protein yields are usually low in fed-batch cultivation (López and de la Torre 2005). Liu et al. (1994) studied the effect of several feeding strategies on vegetative cell growth, spore formation, crystal protein content, carbon dioxide production, and oxygen consumption in fed-batch cultivation of $B t$ subspecies kurstaki. They found that spore and crystals were not formed in fed-batch cultivation. During fed-batch cultivation, there was a redirection of bacterial metabolism which takes place during the feeding.

In $B t$, the setup of transition state was also reported during feeding in fed-batch cultivation. The physiological changes indicated that the transition state was set up during feeding, and it seemed to give a negative effect on sporulation and cry gene expression. Reduced spore count decreased in the percentage of sporulation in fedbatch cultivation with feeding during stationary phase, intermittent feeding, and continuous cultivation as demonstrated in this study could be explained by this mechanism.

Glucose feeding during fed-batch or continuous cultivation also made the glucose not be entirely metabolized in time and resulted in the mass accumulation of organic acids (Wen et al. 2007). Thus, the Krebs cycle activity decreases and the cell is unable to produce sufficient ATP, which in turn reduces the power and biosynthetic intermediates for spore formation (Kim et al. 2003). Nonetheless, fed-batch cultivation of $B t$ subsp. darmstadiensis 032 with an improved $\mathrm{pH}$ and glucose control strategy improved thuringiensis yield significantly (Zhou et al. 2007), though cell growth and sporulation performance were not analyzed. Results from this study demonstrated that the feeding strategy during fed-batch cultivation is crucial and greatly influenced the synthesis of $\delta$-endotoxin.

High cell densities are favorable in fed-batch and continuous cultivations, but yields of spores and cry proteins synthesis were significantly reduced (Arcas et al. 1987; Liu et al. 1994). The reason of why sporulation was affected

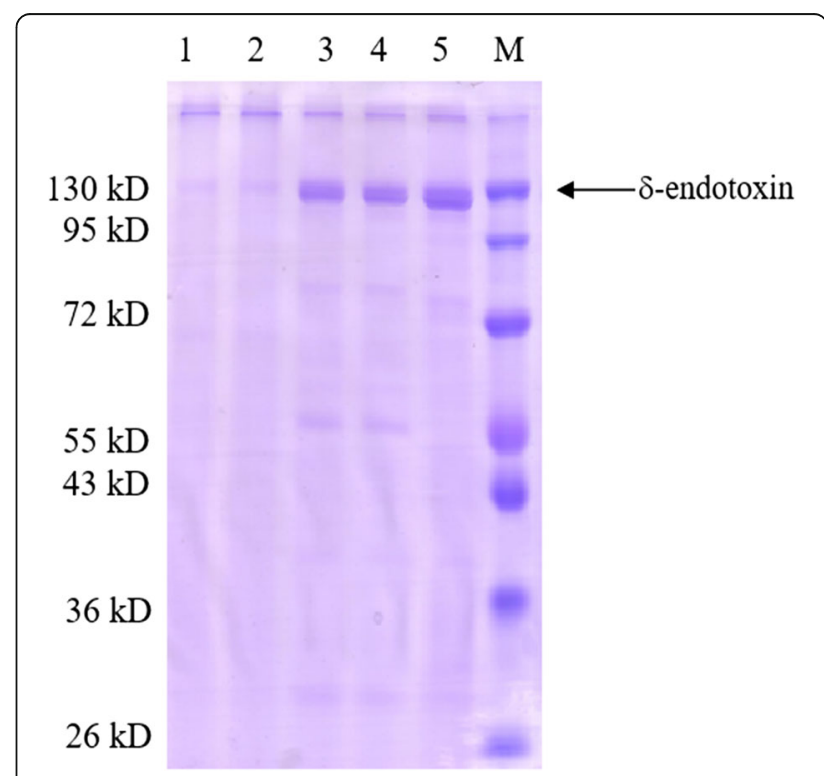

Fig. 5 The SDS-PAGE analysis of $\delta$-endotoxin (130 kD) for Bacillus thuringiensis culture obtained from different modes of cultivation. Cultures, collected at $48 \mathrm{~h}$ of cultivation, were applied to $10 \%$ polyacrylamide gel and stained with Coomassie brilliant blue. M, standard marker; 1 , intermittent fed-batch cultivation with feeding at exponential growth phase and stationary growth phase; 2, fed-batch cultivation with feeding at stationary growth phase; 3 , fed-batch cultivation with feeding at lag growth phase; 4 , fed-batch cultivation with feeding at exponential growth phase; and 5 , batch cultivation 
(A) Oh $4 \mathrm{~h} \quad 8 \mathrm{~h} 12 \mathrm{~h} 16 \mathrm{~h} \quad \mathrm{M} 24 \mathrm{~h} 28 \mathrm{~h} \quad 36 \mathrm{~h} 40 \mathrm{~h} 44 \mathrm{~h} 48 \mathrm{~h}$

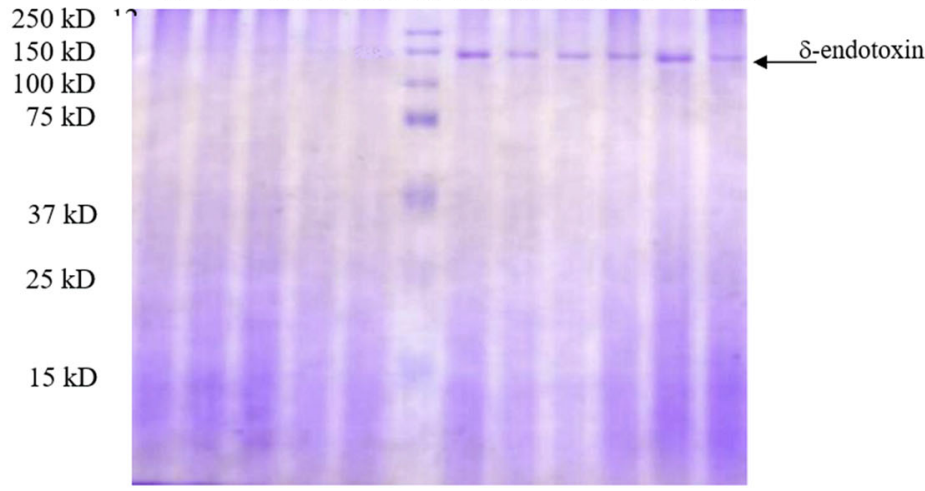

(B) 0h 4 h 8 h $12 \mathrm{~h} 16 \mathrm{~h} \quad \mathrm{M} 24 \mathrm{~h} 28 \mathrm{~h} 36 \mathrm{~h} 40 \mathrm{~h} 44 \mathrm{~h} 48 \mathrm{~h}$

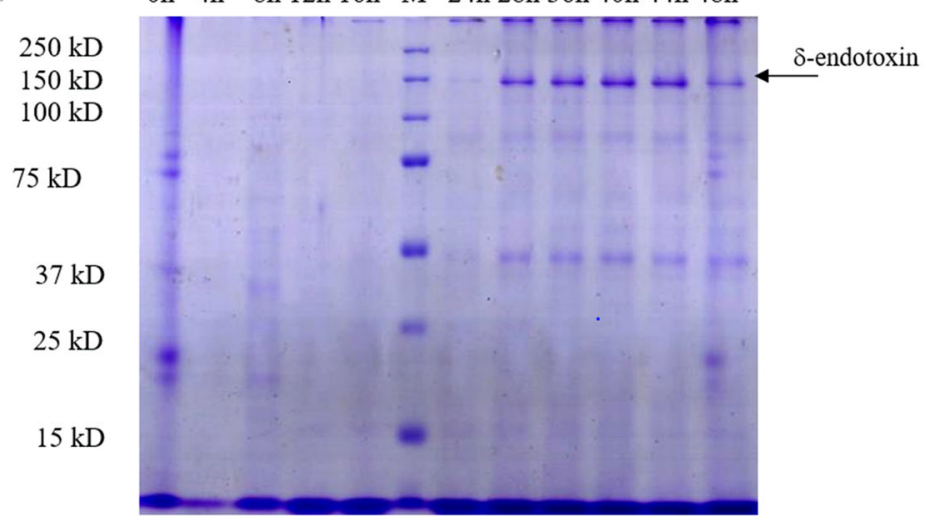

Fig. 6 SDS-PAGE analysis of $\delta$-endotoxin (130 kD) in the cultures of Bacillus thuringiensis MPK13 obtained from a fed-batch cultivation with feeding at lag growth phase, DOT was switched from 80 to $40 \%$ at 8 h, and $\mathbf{b}$ fed-batch cultivation with feeding at exponential growth phase, DOT was switched from 80 to $40 \%$ at $12 \mathrm{~h}$. The cultures were applied to 10\% polyacrylamide gel and stained with Coomassie brilliant blue. M, standard marker

during feeding of a medium can be explained by the transition state regulators that might be overproduced during feeding in the fed-batch or continuous cultivation. Occurrence of catabolite repression is another possible explanation, where excess carbon source in the medium not only causes catabolite repression but also represses the expression of the SpoOA fusion gene that affects sporulation (Yamashita et al. 1989; Lereclus et al. 2000; Sonenshein 2000). Obtained results indicated that feeding the culture with glucose as the carbon source in order to fit the nutrient demand with nutrient availability as a way to obtain high cell densities was not sufficient for the success of higher cell sporulation and better $\delta$-endotoxin production.

\section{Synthesis of $\delta$-endotoxin}

The synthesis of $\delta$-endotoxin at $48 \mathrm{~h}$ of cultivation in batch, fed-batch with feeding at lag, and the exponential growth phase is shown in Fig. 5. No detection of $\delta$ -

Table 3 Corrected mortality of Bacillus thuringiensis MPK13 $\delta$-endotoxin against Metisa plana at 7 and 14 DAT

\begin{tabular}{lll}
\hline & Corrected mortality (\%) & 7 DAT \\
\hline Batch cultivation & 56 & 14 DAT \\
Fed-batch cultivation & 63 & 100 \\
Feeding at lag growth phase & 67 & 100 \\
Feeding at exponential growth phase & 75 & 100 \\
Feeding at lag growth phase; DOT was switched from 80 to $40 \%$ at $8 \mathrm{~h}$ of cultivation & 80 & 100 \\
Feeding at exponential growth phase; DOT was switched from 80 to $40 \%$ at $12 \mathrm{~h}$ of cultivation & 100 \\
\hline
\end{tabular}


endotoxin was recorded in intermittent fed-batch cultivation, fed-batch cultivation with feeding at a stationary growth phase, and also continuous cultivation at all dilution rates. The advantage of batch cultivation can be clearly observed from the time $\delta$-endotoxin was produced ( $28 \mathrm{~h}$ of cultivation). The toxin was synthesized $20 \mathrm{~h}$ earlier than the fed-batch cultivation with feeding at lag and exponential growth phase, where the existence of $\delta$-endotoxin was only detected at $48 \mathrm{~h}$ of cultivation (Table 1). The lack of $\delta$-endotoxin synthesis in the respective culture corresponded to the lowest spore count, the low percentage of sporulation, and also a substantial reduction in spore count $(\geq 40 \%)$ than those obtained in batch cultivation. Feeding of glucose at stationary growth phase, intermittent feeding and continuous feeding throughout the cultivation seemed to promote a high cell growth, thus invading the cells to sporulate. However, with the right DOT control strategy during fedbatch cultivation, enhancement and early synthesis of $\delta$ endotoxin were observed. As shown in Fig. 6a, fed-batch cultivation with fresh medium feeding at lag phase and DOT was switched from 80 to $40 \%$ at $8 \mathrm{~h}$ of cultivation recorded early synthesis (24h of cultivation) of $\delta$ endotoxin while fed-batch cultivation with fresh medium feeding at exponential growth phase and DOT was switched from 80 to $40 \%$ at $12 \mathrm{~h}$ of cultivation recorded thick $130 \mathrm{kD} \delta$-endotoxin bands starting from 28 to $48 \mathrm{~h}$ of cultivation (Fig. 6b).

The absence of $\delta$-endotoxin in intermittent fed-batch cultivation has also been reported. Although intermittent fed-batch cultivation enhanced the growth of $B t$ cell, the sporulation and $\delta$-endotoxin synthesis were significantly reduced ( $\mathrm{Vu}$ et al. 2010). Sasaki et al. (1998) claimed that high cell concentration $(16.1 \mathrm{~g} / \mathrm{l})$ could be obtained in fed-batch cultivation, using sodium acetate-yeast extract (AYE) as a feeding medium, which was fed twice during the cultivation. Nevertheless, a deficient percentage of sporulation was observed after $55 \mathrm{~h}$ of cultivation. In this study, the optimal DOT control strategy was successfully applied in fed-batch cultivation to enhance $\delta$-endotoxin synthesis. Bodizs et al. (2007) reported the importance of DOT regulation using a cascade model in enhancing the industrial pilot-scale fed-batch fungal fermentation. In this study, the change of DOT from a high level ( $80 \%$ saturation) to a low level (60\% saturation) promoted sporulation rate and triggered $\delta$-endotoxin synthesis without significantly affecting the cell growth.

\section{Toxicity against Metisa plana}

The toxicity of $\delta$-endotoxin, obtained from $B t$ MPK13 cultures, was tested against M. plana. The highest corrected mortality (80\%) at 7 DAT (days of treatment) and 14 DAT (100\% mortality) was recorded by the culture obtained from fed-batch cultivation with feeding during the exponential growth phase, and the DOT was switched from 80 to $40 \%$ at $12 \mathrm{~h}$ of cultivation (Table 3). Culture from fed-batch cultivation with feeding during the lag growth phase and the DOT was switched from 80 to $40 \%$ at $8 \mathrm{~h}$ of cultivation exhibited the second highest corrected mortality $(75 \%)$ at 7 DAT. For culture obtained from batch cultivation, the corrected mortality recorded at 7 DAT was $56 \%$. For cultures obtained from fed-batch cultivation without DOT control strategy, either feeding at lag or exponential growth phase, the corrected mortality recorded at 7 DAT was not more than $67 \%$. It is important to note that all cultures containing $\delta$ endotoxin exhibited $100 \%$ mortality towards M. plana at 14 DAT (Table 3).

All cultures that contain $\delta$-endotoxin during the cultivation recorded a high corrected mortality rate $(\geq$ $55 \%$ mortality) towards the bagworm $M$. plana at 7 DAT. The $100 \%$ mortality of the bagworm at 14 DAT after exposure to the $\delta$-endotoxin further confirms the high-efficacy effect of $B t$ MPK13 on the lepidopteran pest.

\section{Conclusion}

The results of this study demonstrated that the fedbatch had the potency to increase $B t$ cell growth than the batch cultivation. However, the fed-batch cultivation, with feeding during the stationary growth phase and intermittent feeding, did not support high spore production as the system was supplied with the highest concentration of glucose during the cultivation. The synthesis of $\delta$-endotoxin, with a molecular weight of $130 \mathrm{kD}$, was detected in batch and constant fedbatch cultivations with feeding at lag or exponential growth phase. The capability of fed-batch cultivation, with feeding during lag or exponential growth phase, can be enhanced significantly with the application of optimal DOT control strategy.

\section{Abbreviations \\ CFU: Colony-forming unit; DAT: Day after treatment; DOT: Dissolved oxygen tension; EC: Emulsified concentrate; rpm: Rotation per minuteATPAdenosine triphosphate \\ Acknowledgements \\ The authors would like to thank the Director General of Malaysian Palm Oil Board for the permission to publish this article. We greatly appreciate all the staff from Microbial Technology and Engineering Center (MICROTEC), especially to Mr. Zamri Daud and Mr. Aminshah Abd Aziz for their valuable assistance. We would also like to thank Dr. Norman Kamarudin for his comments and support for this study.}

\section{Authors' contributions}

MMMM and $A B A$ designed the experiment. MMMM conducted the experiment and drafted the manuscript. ABA helped in data analysis and added inputs in the drafted manuscript. Both authors read and approved the final manuscript. 


\section{Funding}

The study was supported financially by MPOB.

\section{Availability of data and materials}

The datasets used and analyzed during the study are available from the corresponding author on reasonable request.

\section{Ethics approval and consent to participate}

Not applicable

\section{Consent for publication}

Not applicable

\section{Competing interests}

The authors declare that they have no competing interests.

\section{Author details}

${ }^{1}$ Applied Entomology and Microbiology Unit, Biological Research Division, Malaysian Palm Oil Board, 43000 Kajang, Selangor, Malaysia. ²Department of Bioprocess Technology, Faculty of Biotechnology and Biomolecular Sciences, Universiti Putra Malaysia, UPM, 43400 Serdang, Selangor, Malaysia.

Received: 16 October 2019 Accepted: 5 January 2020

Published online: 15 January 2020

\section{References}

Abbott WS (1987) A method of computing the effectiveness of an insecticide. J Am Mosquito Contr. 3(2):302-303

Adams T, Eiteman MA, Adang MJ (1999) Bacillus thuringiensis subsp. kurstaki spore production in batch culture using broiler litter extracts as complex media. Bioresource Technol 67:82-87

Agaisse H, Lereclus D (1995) How does Bacillus thuringiensis produce so much insecticidal crystal protein. J Bacteriol 177(21):6027-6032

Arcas J, Yantorno O, Ertola R (1987) Effect of high concentration of nutrients on Bacillus thuringiensis cultures. Biotechnol Lett 9:105-110

Aronson Al, Yechiel S (2001) Why Bacillus thuringiensis toxins are so effective: unique features of their mode of action. FEMS Microbiol Lett 195:1-8

Avionone-Rossa C, Mignone C (1993) $\delta$-endotoxin activity and spore production in batch and fed-batch cultures of Bacillus thuringiensis. Biotech Lett 15(3): 295-300

Basri MW, Hassan AH, Zulkefli M (1988) Bagworms (Lepidoptera: Psychidae) oil palm in Malaysia. PORIM Occasional Paper 23:37

Basri MW, Siti Ramlah AA, Norman K (1994) Status report on the use of Bacillus thuringiensis in the control of some oil palm pests. Elaeis 6(2):82-101

Bodizs L, Titica M, Faria N, Srinivasan B, Dochain D, Bonvin D (2007) Oxygen control for an industrial pilot-scale fed-batch filamentous fungal fermentation. J Process Control 17:595-606

Brian JW, Norman K (2019) Bagworm (Lepidoptera: Psychidae) infestation in the centennial of the oil palm industry a review of causes and control. J Oil Palm Res 31(3):364-380 https://doi.org/10.21894/jopr.2019.0032

Içygen Y, Içygen B, Ózcengiz G (2002) Regulation of crystal protein biosynthesis by Bacillus thuringiensis: I. Effects of mineral elements and $\mathrm{pH}$. Res Microbio 153:599-604

Kang BC, Lee SY, Chang HN (1993) Production of Bacillus thuringiensis spores in total cell retention culture and two-stage continuous culture using an internal ceramic filter system. Biotech Bioengineering 42:1107-1112

Khodair TQ, Abdelhafez AAM, Sakr HM, Ibrahim MMM (2008) Improvement of Bacillus thuringiensis bioinsecticides production by fed-batch culture on lowcost, effective medium. Res J Agric Biol Sci 4(6):923-935

Kim HJ, Kim SS, Ratnayake-Lecamwasam M, Tachikawa K, Sonshein AL, Strauch M (2003) Complex regulation of the Bacillus subtilis aconitase gene. J Bacteriol. 185:1672-1680

Krause M, Ukkonen K, Haataja T, Ruottinen M, Glumoff T, Neubauer A, Neubauer P. Vasala A (2010) A novel fed-batch based cultivation method provides high cell-density and improves yield of soluble recombinant proteins in shaken cultures. Microb Cell Fact 9(11):1475-2859

Laemmli UK (1970) Cleavage of structural proteins during the assembly of the head of bacteriophage T4. Nature. 227(5259):680-685

Lereclus D, Argaisse H, Grandvalet C, Gominent M (2000) Regulation of toxin and virulence gene transcription in Bacillus thuringiensis. Int J Med Microbiol 29: 295-299
Liu WF, Bajpal R, Binary V (1994) High-density cultivation of spore formers. Ann NY. Acad Sci 721:310-325

López LVE, de la Torre M (2005) Redirection of metabolism during nutrient feeding in fed-batch cultures of Bacillus thuringiensis. Appl Microbiol Biotechnol 67:254-260

Mazmira MMM, Ramlah SAA, Rosfarizan M, Ling TC, Ariff AB (2012) Effect of saccharides on growth, sporulation rate and $\delta$-endotoxin synthesis of Bacillus thuringiensis. Afr J Biotechnol 11(40):9654-9663

Mazmira MMM, Ramlah SAA, Rosfarizan M, Ling TC, Ariff AB (2013) Relationship between total carbon, total nitrogen and carbon to nitrogen ratio on growth, sporulation rate and delta-endotoxin synthesis of Bacillus thuringiensis. Minerva Biotecnologica 25(4):219-225

Mazmira MMM, Siti Ramlah AA, Najib MA, Norman K, Kushairi AD, Basri MW (2010) Integrated pest management (IPM) of bagworms in Southern Perak via aerial spraying of Bacillus thuringiensis. Oil Palm Bull 63:24-33

Noorhazwani K, Siti Ramlah AA, Mazmira MMM, Najib MA, Che Manan CAH, Norman K (2017) Controlling Metisa plana Walker (Lepidoptera: Psychidae) outbreak using Bacillus thuringiensis at an oil palm plantation in Slim River, Perak, Malaysia. J Oil Palm Res 29(1):47-54

Norman K, Mazmira MM (2019) Industry-wide efforts in circumventing the scourge of bagworm infestation in Malaysia - what have gone wrong and what should be done? Planter 95(1118):321-333

Rajalakshmi S, Shethna YI (1980) Spore and crystal formation in Bacillus thuringiensis during growth in cystine and cysteine. J Bioscience 2(4):321-328

Ramlah SAA, Norman K, Basri MW, Najib MA, Mazmira MMM, Kushairi AD (2007) Sistem pengurusan perosak bersepadu bagi kawalan ulat bungkus di ladang sawit. MPOB publication 28

Rech R, Ayub MAZ (2007) Simplified feeding strategies for fed-batch cultivation of Kluyveromyces marxianus in cheese whey. Process Biochemistry 42:873-877

Rowe GE, Margaritis A (1987) Bioprocess developments in the production of bioinsecticides by Bacillus thuringiensis. CRC Crit Rev Biotechnol. 6:87-127

Sarrafzadeh MH, Belloy L, Esteban G, Navarro JM, Ghonmidh C (2005) Dielectric monitoring of growth and sporulation of Bacillus thuringiensis. Biotech Lett 27:511-517

Sasaki K, Jiaviriyaboonya S, Rogers PL (1998) Enhancement of sporulation and crystal toxin production by corn steep liquor feeding intermittent fed-batch culture of Bacillus sphaericus 2362. Biotech Lett 20(2):165-168

Sonenshein AL (2000) Control of sporulation initiation in Bacillus subtilis. Curr Opin Microbiol. 3:561-566

Stanbury PF, Whitaker PF, Hall SJ (2003) Principles of fermentation technology, 2nd edn. Butterworth, Heinemann

Tey CC, Cheong YL (2013) Challenges in integrated pest management (IPM). Proc. of $10^{\text {th }}$ NATSEM 2013 - confronting management challenges in the oil palm industry. Incorporated Society of Planters, Kuala Lumpur, pp 117-127

Thompson PJ, Stevenson KE (1984) Mesophilic spore-forming aerobes. In: Speck $M$ (ed) Compendium of methods for the microbiological examination of foods. American Public Health Association, Washington, pp 211-220

Vu KD, Tyagi RD, Valero JR, Surampalli RY (2010) Batch and fed-batch fermentation of Bacillus thuringiensis using starch industry wastewater as fermentation substrate. Bioprocess Biosyst Eng 33(6):691-700

Warren B, David BL, Nazim C (2018) Bioreactor operating strategies for improved polyhydroxyalkanoate (PHA) productivity. Polymers 10:1197 https://doi.org/ 10.3390/polym10111197

Wen ZJ, Fei CY, Hong XZ, Niu YZ, Wen CS (2007) Production of thuringiensis by fed-batch culture of Bacillus thuringiensis subsp. darmstadiensis 032 with an improved pH-control glucose feeding strategy. Process Biochem 42:52-56

Yamashita S, Kawamura F, Yoshikawa H, Takahashi H, Kobayashi Y, Saito H (1989) Dissection of the expression signals of the SpoOA gene of Bacillus subtilis: glucose represses sporulation specific expression. J Gen Microbiol 135(5):1335-1345

Yury VM, Anton AN, Kirill SA (2019) Repertoire of the Bacillus thuringiensis virulence factors unrelated to major classes of protein toxins and its role in the specificity of host-pathogen interactions. Toxins 11:347 https://doi.org/10.3390/toxins11060347

Zhou JW, Cheng YF, Xu ZH, Yu ZN, Chen SW (2007) Production of thuringiensis by fed-batch culture of Bacillus thuringiensis subsp. darmstadiensis 032 with an improved $\mathrm{pH}$ control feeding strategy. Process Biochem 42:52-56

\section{Publisher's Note}

Springer Nature remains neutral with regard to jurisdictional claims in published maps and institutional affiliations. 